\title{
Lesson Study in Improving the Role of E-Portfolio on the Metacognitive Skill and Concept Comprehension: A Study on Cell Biology Subject in IKIP PGRI Madiun, Indonesia
}

\author{
Marheny Lukitasari ${ }^{1}$, Herawati Susilo ${ }^{2}$, Ibrohim ${ }^{2}$, A. Duran Corebima ${ }^{2, *}$ \\ ${ }^{1}$ Faculty of Mathematics and Natural Science Education, IKIP PGRI MADIUN, Madiun, Indonesia \\ ${ }^{2}$ Faculty of Mathematics and Science, State University of Malang, Malang, Indonesia \\ *Corresponding author: durancorebima@yahoo.com
}

Received October 10, 2014; Revised October 16, 2014; Accepted October 19, 2014

\begin{abstract}
The purpose of the study was to examine the potency of the implementation of e-portfolio supported by the implementation of Lesson Study to improve the metacognitive skill and concept comprehension of Cell Biology. The activities of the lesson study aimed for developing and enhancing e-portfolio implementation habit carried out done seventh times with the same Cell Biology material. The study was followed by quasi experimental study conducted on two classes, consisting of 26 and 27 students. One class underwent seven meetings of portfolio and another class underwent seven meetings of e-portfolio. The data of the study related to the concept comprehension were obtained by valid and reliable pretest and posttest. The data related to the metacognitive skill were obtained too by the pretest and posttest supported by a special rubric. The data of the lesson study were analyzed qualitatively. The data of the quasi experimental study were analyzed by ANACOVA test, to uncover the difference between the two treatments. The results of the study showed that there were significant effects of the implemented treatment on the metacognitive skill and the cell biology concept comprehension of the students. The average score of the metacognitive skill of e-portfolio class supported by lesson study was 39,4\% higher than that of the portfolio class. The average score of the concept comprehension of e-portfolio class supported by lesson study was $15 \%$ higher than that of the portfolio class without lesson study. The implementation of lesson study was significantly effective in improving the metacognitive skill and the concept comprehension of e-portfolio class compared to that of portfolio class, regardless the previous research reported that the implementation of e-portfolio had unsignificant effect.
\end{abstract}

Keywords: lesson study, E-portfolio, metacognitive skill, concept comprehention, cell biology

Cite This Article: Marheny Lukitasari, Herawati Susilo, Ibrohim, and A.Duran Corebima, "Lesson Study in Improving the Role of E-Portfolio on the Metacognitive Skill and Concept Comprehension: A Study on Cell Biology Subject in IKIP PGRI Madiun, Indonesia." American Journal of Educational Research, vol. 2, no. 10 (2014): 919-924. doi: 10.12691/education-2-10-11.

\section{Introduction}

Nowadays, the implementation of internet facility and other kind of technology as one of supporting learning process are common, even are required to be done supporting the process of education in the $21^{\text {st }}$ century for the last twenty years. However, many people do not use the facility properly, especially in the world of education, which impact to the result of the education. Reference [1] shows study related to the Internet and the technology support on learning, in form of e-portfolio, did not show a significant effect to the students' learning results. The similar case was also confirmed as in [2] that the eportfolio support did not show a significant effect on the improvement of the students' motivation and learning results. Even though a number of studies related to the implementation of e-portfolio are reported to be able to contribute positive impact, the relative new means do not always reveal the expected result. Whereas, the support of the implementation of IT in form of e-portfolio should be able to be used optimally, especially to enhance the technology skill in saving data and modifying various information so that it eases the learning process and improves the learning result e.g. [3,4,5]).

The implementation of e-portfolio, which affect the learning result including the concept comprehension related to certain materials, is closely related to the metacognitive skill. Reference [6] shows that the metacognitive skill is a skill to predict the learning process. Furthermore based on their research result, as in [7], that the metacognitive skill, executed step by step will help organizing any complex assignment, and it was perceived as a kind of the metacognitive performance. Reference [8] shows that the learning process structured would loosen the brain memory load. Also reference [9] shows that the metacognitive skill bring positive impact on students' 
learning results. In terms of the implementation of eportfolio, Reference [10] shows that this facility enabled the students to understand their own ability to describe their condition and this ability belonged to metacognitive skill. Thus, it can be stated that e-portfolio is able to be used to train the students metacognitive skill so that it affect their concept comprehension.

Reference [11] shows that the integration of e-portfolio in syllabus would make the facility be more planned, well arranged, and monitored so that it contributed to the expected learning results. Reference [12] and [13] shows stated that the implementation of e-portfolio facilitated several activities such as peer assessment, reflection, and evaluation so that it enhanced the students' responsibility and individual skill belonging to metacognitive skill. Reference [14] added that the implementation of eportfolio could describe and conveyed the students' learning experiences through selection, colllection, and reflection on the learning result. Besides, as one of supporting facilities of learning process and evaluation, the e-portfolio had been vastly implemented in European countries (e.g. $[4,5,15])$.

Based on the result of the studies mentioned, it is questionable if the implementation of e-portfolio can improve the metacognitive skill and concept comprehension in Indonesia? Is there any obstacle of the e-portfolio implementation? How to make e-portfolio as a potential tool to improve the metacognitive skill and concept comprehension? It is necessary to integrate eportfolio to another activity so it can bring positive effect to the learning process and the learning results. This effort is important since the implementation of e-portfolio is relatively new as well as promising to empower the development of education.

One of efforts to optimize the effect of e-portfolio in learning activity is the implementation of lesson study as an integral part of the learning process. There were many studies related to the implementation of lesson study showing the increasing of learning quality (e.g. [16,17]) and affecting the students' learning result (e.g. [18,19]). An increasing of the quality of the lecturer and will also affect the learning quality in terms of the material focus, experience enrichment, confidence, peer feedback, experience sharing, and problem solving.

Lesson study had been implemented firstly in Indonesia in 2001 related to IMSTEP-JICA Project program in Bandung-West Java, Yogyakarta-Central Java, and Malang-East Java, as in [20]. In 2010 the lesson study was implemented at IKIP PGRI MADIUN in Mathematics and Natural Science Faculty especially in Mathematics, Physics, and Biology Department [21]. The result of the lesson study showed an increasing of learning quality especially related to those lectures studied at the three departments. According to [22] the implementation of lesson study will increase the quality of (a) student collaboration in learning activity, (b) the implementation of contextual learning, (c) life skill, (d) learning activity, (e) interaction process based on the curriculum and syllabus development, and (f) students-lecturer interaction. In the implementation, lesson study can be applied to any subjects including Cell Biology.

Cell Biology subject is an obliged subject for Biology students. The material tends to be abstract thus many students think that cell biology subject is a difficult subject to be learnt due to its abstract characteristics. Reference [23] shows that the difficulty level of the Cell Biology subject is high for it covers many materials such as the main differences of prokaryotic cell and eukaryotic cell, the structure and the function of organelle cells, cells metabolism, cells reproduction called mitosis and meiosis, cells communication, necrosis, and research development related to cells. In this case, it is necessary to apply appropriate techniques to activate and motivate the students to obtain the learning objectives. The implementation of e-portfolio supported by share and comment activity through lesson study provides a posibility of unlimited active interactions among students.

Considering the above mentioned explanation, it is necessary to discuss the role of e-portfolio conducted through lesson study so it affects positively to students and lecturers. Hence, the study wants to examine the effect of the implementation of e-portfolio through lesson study on the increasing of the metacognitive skill and the concept comprehension of the students related to the Cell Biology subject.

\section{The Sample of the Study}

The sample of the study were two parallel classes of second semester students of academic year 2013/2014 programing the Cell Biology subject. Those classes underwent lesson study before the experimentation, to implement e-portfolio as well as portfolio. The lesson study consisted of seven meetings for each class with the same Cell Biology material. So, there were fourteeen meetings of lesson study overall.

The two classes were used as two groups, namely the experimental group and the control group. The experimental group consisting of 27 students underwent eportfolio, and the control group consisting of 26 students underwent portfolio.

\section{The Procedure of the Study}

\subsection{The Lesson Study Implementation}

The lesson study was carried out by teams consisting of seven lecturers of Biology Department and eleven students of seventh semester programing thesis. The lecturers had known and underwent lesson study program in 2010-2012. Three of those lecturers had ever become modeling lecturers at their mastery subjects.

The plan-do-see cycle was conducted seven times at each class so there were fourteen cycles of lesson study at the two classes related to the same material. The cycles of the lesson study of the two classes are presented in the following Figures.

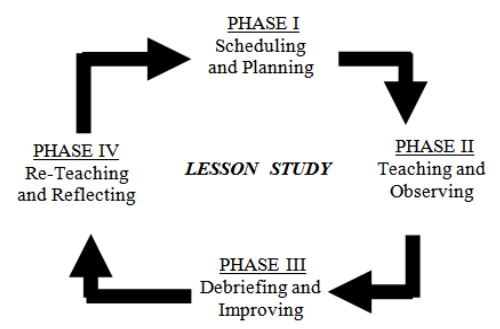

Figure 1. The cycle of lesson study (Smith, 2010) 


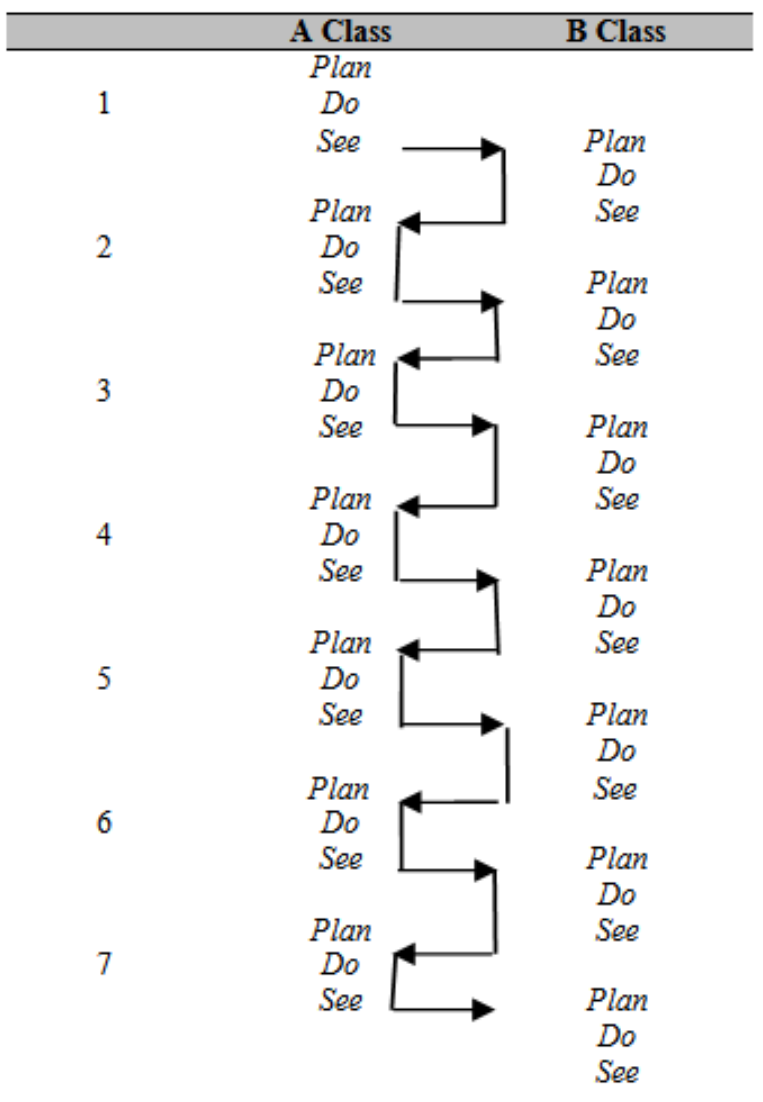

Figure 2. The cycle application in sample classes

Table 1. The Lesson Study Schedule of the Two Sample Classes

\begin{tabular}{|c|c|c|c|c|c|}
\hline No & Material & $\begin{array}{l}\text { Plan } \\
\text { (Phase } \\
\text { I) }\end{array}$ & $\begin{array}{c}\text { Do-See } \\
\text { (Phase } \\
\text { II) }\end{array}$ & $\begin{array}{l}\text { Plan } \\
\text { (Phase } \\
\text { III) }\end{array}$ & $\begin{array}{c}\text { Do-See } \\
\text { (Phase } \\
\text { IV) } \\
\end{array}$ \\
\hline 1 & $\begin{array}{l}\text { The cell structure, } \\
\text { advantages and } \\
\text { disadvantages of } \\
\text { learning Cell } \\
\text { Biology, tools and } \\
\text { technique of } \\
\text { learning cell }\end{array}$ & $\begin{array}{l}18^{\text {th }} \\
\text { March } \\
2013\end{array}$ & $\begin{array}{l}22^{\text {nd }} \\
\text { March } \\
2013 \\
\text { (Class } \\
\text { A) }\end{array}$ & $\begin{array}{c}22^{\text {nd }} \\
\text { March } \\
2013 \\
\text { (Class B) }\end{array}$ & $\begin{array}{c}24^{\text {th }} \\
\text { March } \\
2013 \\
\text { (Class B) }\end{array}$ \\
\hline 2 & $\begin{array}{l}\text { The function of } \\
\text { organic and } \\
\text { inorganic chemical } \\
\text { component. }\end{array}$ & $\begin{array}{l}29^{\text {th }} \\
\text { March } \\
2013\end{array}$ & $\begin{array}{c}1^{\text {st }} \\
\text { April } \\
2013 \\
\text { (Class } \\
\text { B) } \\
\end{array}$ & $\begin{array}{l}1^{\text {st }} \text { April } \\
2013 \\
\text { (Class A) }\end{array}$ & $\begin{array}{l}3^{\text {rd }} \text { April } \\
2013 \\
\text { (Class A) }\end{array}$ \\
\hline 3 & $\begin{array}{l}\text { The basic structure } \\
\text { of cell membrane } \\
\text { and the permeability }\end{array}$ & $\begin{array}{l}1^{\text {st }} \\
\text { April } \\
2013\end{array}$ & $\begin{array}{c}8^{\text {th }} \\
\text { April } \\
2013 \\
\text { (Class } \\
\text { B) }\end{array}$ & $\begin{array}{l}8^{\text {th }} \text { April } \\
2013 \\
\text { (Class A) }\end{array}$ & $\begin{array}{l}10^{\text {th }} \text { April } \\
2013 \\
\text { (Class A) }\end{array}$ \\
\hline 4 & $\begin{array}{c}\text { Endomembrane } \\
\text { System; Supporting } \\
\text { Organelle }\end{array}$ & $\begin{array}{l}11^{\text {th }} \\
\text { April } \\
2013\end{array}$ & $\begin{array}{l}15^{\text {th }} \\
\text { April } \\
2013 \\
\text { (Class } \\
\text { B) }\end{array}$ & $\begin{array}{l}15^{\text {th }} \text { April } \\
2013 \\
\text { (Class A) }\end{array}$ & $\begin{array}{l}17^{\text {th }} \text { April } \\
2013 \\
\text { (Class A) }\end{array}$ \\
\hline 5 & $\begin{array}{l}\text { The structure and } \\
\text { the function of } \\
\text { Cytoskeleton }\end{array}$ & $\begin{array}{l}18^{\text {th }} \\
\text { April } \\
2013\end{array}$ & $\begin{array}{l}26^{\text {th }} \\
\text { April } \\
2013 \\
\text { (Class } \\
\text { A) } \\
\end{array}$ & $\begin{array}{l}26^{\text {th }} \text { April } \\
2013 \\
\text { (Class B) }\end{array}$ & $\begin{array}{l}27^{\text {th }} \text { April } \\
2013 \\
\text { (Class B) }\end{array}$ \\
\hline 6 & $\begin{array}{l}\text { The structure and } \\
\text { the function of } \\
\text { mitochondria and } \\
\text { chloroplast }\end{array}$ & $\begin{array}{l}29^{\text {th }} \\
\text { April } \\
2013\end{array}$ & $\begin{array}{c}2^{\text {nd }} \\
\text { May } \\
2013 \\
\text { (Class } \\
\text { A) }\end{array}$ & $\begin{array}{c}2^{\text {nd }} \text { May } \\
2013 \\
\text { (Class B) }\end{array}$ & $\begin{array}{l}4^{\text {th }} \text { May } \\
2013 \\
\text { (Class B) }\end{array}$ \\
\hline 7 & $\begin{array}{l}\text { The nucleus and } \\
\text { genetic material }\end{array}$ & $\begin{array}{l}6^{\text {th }} \text { May } \\
2013\end{array}$ & $\begin{array}{l}9^{\text {th }} \text { May } \\
2013 \\
\text { (Class } \\
\text { A) }\end{array}$ & $\begin{array}{c}9^{\text {th }} \text { May } \\
2013 \\
\text { (Class B) }\end{array}$ & $\begin{array}{c}11^{\text {th }} \text { May } \\
2013 \\
\text { (Class B) }\end{array}$ \\
\hline
\end{tabular}

Figure 1 and Figure 2 explaind the cycle of the lesson study by Smith (2010) and implied on two sample classes.
The first step preceding the learning activity was the explanation of the e-portfolio by the lecturer and its component included of assignment that must be brought about by the students. In this step, the lecturer also demonstrated the way to operate the e-portfolio web provided. Based on the Figure 1, the schedule and the Cell Biology material of the lesson study applied at the two classes is presented in Table 1.

\subsection{The Implementation of The Quasi Experiment}

The implementation of quasi experimental study was conducted in seven meetings after developing e-portfolio and lesson study of Cell Biology. The Biology material used in the quasi experiment were: the structure and the function of mitochondria and chloroplast, the structure and the function of nucleus, genetic material and DNA replication; the structure and the function of ribosom and Protein Synthesis mechanism, cell cycle and the mechanism of mitosis and meiosis, the interaction and the communication of cells, apoptosis, necrosis, cell aging, stem cell, and cell regeneration. The procedure of the quasi experiment is showed on Table 2.

Table 2. The Procedure of the Implementation of Quasi Experimental Study (Tuckman, 1999)

\begin{tabular}{ccc}
\hline Pretest & Group & Posttest \\
\hline $\mathrm{T} 1$ & $\mathrm{X} 1$ & $\mathrm{~T} 2$ \\
\hline $\mathrm{T} 3$ & $\mathrm{X} 2$ & $\mathrm{~T} 4$ \\
\hline
\end{tabular}

T1 and T3 refer to the pretest

$\mathrm{T} 2$ and $\mathrm{T} 4$ refer to the posttest

$\mathrm{X} 1$ refers to the e-portfolio experimental group

$\mathrm{X} 2$ refers to the portfolio control group

\section{The Data of the Study and the Data Analysis}

The data of the lesson study were obtained from observation sheet, interviews to the lecturers and the students, and field note of the lesson study implementation. The data were analyzed by applying data reduction technique as well as by concluding qualitatively.

There were two data obtained from the quasi experimental study, namely (1) the pretest and posttest scores related to concept comprehension of Cell Biology and (2) the pretest and posttest score of metacognitive skill. The pretest and posttest scores of concept comprehension as well as of metacognitive skill were measured by the same essay test proven valid and reliable. The metacognitive score were computed by the formula adopted from Corebima (2006).

$$
Y 1=\frac{X+2 Y 2}{3}
$$

Y1 refers to combined score of the concept comprehension and the metacognitive skill (scoring process is carried out based on the spesific rubric)

$\mathrm{X}$ refers to the metacognitive skill score

Y2 refers to the concept comprehension score minimizing the metacognitive skill aspect

The data of the concept comprehension and the metacognitive skill were analyzed by using one way ANACOVA test supported by SPSS program version of 17 . 


\section{Findings}

\subsection{The Results of Lesson Study}

The implementation of lesson study supporting and habituating the application of e-portfolio by students of Cell Biology classes ran very good. The modeling lecturer and the members of lesson study team always discussed the lesson plan before the lecturing activities were done. In the discussion process, the members of the team consisting of lecturers and students of the last semester gave several constructive feedbacks for the better lecturing process. The members also conveyed that there were many advantages in terms of developing their professionalism and lecturing experience by the implementation of lesson study. One of them stated below.

I think the Cell Biology material will be delivered much more better so that the explanation will be more interesting and clearer. This condition is the core aspect to manage the class well. (See, $17^{\text {th }}$ April 2013).

The e-portfolio design indirectly gave an advantage for the team members, especially in terms of the implementation of IT integrated with e-portfolio. In the reflection session, there can be seen that one of the team members showed some interest in applying e-portfolio during her learning process for this activity encourages the students and helps them to reflect their learning results. As for the modeling lecturer, the advantage of e-portfolio adopted at lesson study enhances their confidence. Thus, it eases the process of the lecturing. This was reflected from the comment of one of team members below.

As a lecturer, I am interested in applying e-portfolio. Considering the implementation so far, I think students show their enthusiasm and interest, and feel the challenge of each planned assignment and upload it. This can be the positive value of the implementation of e-portfolio in learning activity even though we know that in the beginning we might face few obstacles. (See, $26^{\text {th }}$ April 2013).

Most students also felt the direct impact of the lesson study in increasing the role of e-portfolio implementation in Cell Biology class. The discussion method based on the given and uploaded assignments in form of e-portfolio, enables the students to manage their own time. On the other side, some students conveyed that they always recheck and revise their assignments before uploading them. Therefore, the students had enriched their knowledge indirectly by relearning the given materials. This condition shows that the student metacognitive skill is trained through the evaluation and reflection activities.

The habituation of e-portfolio through lesson study in group can also activate the students in the lecturing process. It also enhances the students' concept comprehension related to Cell Biology material. The discussion and sharing process by comment media and share activity through e-portfolio stimulate the students to be careful towards important point in the given material. Additional information might also be attained during the discussion activity since there is a link of the materials appeared in the discussion forum. Hence, it can enrich the source of the topic being discussed.

The implementation of lesson study basically gives experience and new discourse in terms of adjusting and enhancing the quality of learning. Some difficulties might be felt in the beginning of the process, especially in terms of adapting the schedule and adjusting the topic discussion perception. However, as the activity done, the team will be more solid and it will be easier to cooperate and share knowledge.

\subsection{The Results of the Quasi Experimental Study}

The implementation of lesson study followed by quasi experimental study on two classes by giving different treatments, namely portfolio and e-portfolio, were aimed to examine the effect of the treatments. The analysis result related to the metacognitive skill and the concept comprehension using ANACOVA are presented in the following Table 3 and Table 4.

Table 3. The Effect of the e-portfolio Implementation on the Student Metacognitive Skill

\begin{tabular}{|c|c|c|c|c|c|}
\hline \multicolumn{6}{|c|}{ Dependent Variabe: Postest } \\
\hline source & Type III Sum of Squares & df & Mean Square & $\mathrm{F}$ & Siq. \\
\hline Corrected Model & $1198.140 \mathrm{a}$ & 2 & 599.070 & 5.019 & .010 \\
\hline Intercept & 20435.142 & 1 & 20435.142 & 171.220 & .000 \\
\hline Pretest & 22.094 & 1 & 22.094 & .185 & .669 \\
\hline Metode & 1170.656 & 1 & 1170.656 & 9.809 & .003 \\
\hline Error & 5967.497 & 50 & 119.350 & & \\
\hline Total & 50832.687 & 53 & & & \\
\hline Corrected Total & 7165.637 & 52 & & & \\
\hline
\end{tabular}

a. R Squared $=.167$ (Adjusted R Squared $=.134$ )

The result of the ANACOVA test showed on Table 3 revealed that the critical value is smaller than the significant value 0.05 . It means that there is a treatment effect towards the students' metacognitive skill. Based on the result of anacova test, the average score of the eportfolio metacognitive skill of the students is $39,4 \%$ higher than that of the portfolio metacognitive skill.

Table 4. The Effect of the e-portfolio Implementation on the Student Concept Comprehension

\begin{tabular}{|c|c|c|c|c|c|}
\hline \multicolumn{6}{|c|}{ Dependent Variable Postest } \\
\hline Source & Type III Sum of Squares & $\mathrm{df}$ & Mean Square & $\mathrm{F}$ & Siq. \\
\hline Corrected Model & $1506.475 a$ & 2 & 753.238 & 7.570 & .001 \\
\hline Intercept & 4166.899 & 1 & 4166.899 & 41.875 & .000 \\
\hline Pretest & 139.096 & 1 & 139.096 & 1.398 & .243 \\
\hline Metode & 1074.174 & 1 & 1074.174 & 10.795 & .002 \\
\hline Error & 4975.430 & 50 & 99.509 & & \\
\hline Total & 285012.408 & 53 & & & \\
\hline Corrected Total & 6481.905 & 52 & & & \\
\hline
\end{tabular}

a. R Squared $=.232$ (Adjusted R Squared $=.202$ ) 
The result of the ANACOVA test (Table 4) revealed that the critical value is smaller than the significance value of 0.05. It means that the treatment affect on the student concept comprehension of Cell Biology material. The average score of the e-portfolio concept comprehension of the students is $15 \%$ higher than that of the portfolio concept comprehension.

\section{Discussion}

The result of the study proved that the process of lesson study can improve the quality of learning especially in terms of the planning, action, and evaluation of arranging and the implementation of e-portfolio. In other words, consistent implementation of lesson study can affect the professionalism of lecturers in teaching (e.g. [18,27]). The implementation of e-portfolio affected significantly student metacognitive skill and concept comprehension as can be seen in Table 3 and Table 4 . The more the lesson study team involve in discussion, knowledge sharing, observation, as well as focus the discussion topic, the more they comprehend and improve their lecturer professionalism, as in (e.g.[28,29]). The increasing of lecturing professionalism affect the lecturing quality and the students' learning result.

The implementation of this lesson study needs to be applied continuously. The e-portfolio implementation supported by lesson study showing a significant effect on the students' metacognitive skill and concept comprehension of Cell Biology is different from [2] study. Whereas [30] showing that the implementation of eportfolio could improve the management of learning process skill and it belongs to the metacognitive skill. Therefore, the implementation of lesson study might answer the need of improving learning quality affecting the students' learning result, especially related to the metacognitive skill supported by structured tasks. Reference [31] shows that the metacognitive skill can positively affect the concept comprehension through the implementation of e-portfolio.

The lesson study activity planned and conducted systematically before the quasi experimental study makes the learning process of Cell Biology more efficient especially in terms of developing the lesson plan. The modeling lecturer also attain many constructive feedbacks related to the material, time allocation, teaching technique and assignment, as well as evaluation type related to eportfolio. The similar result in terms of the developed lesson plan was in [32,33], related to the increasing of teaching professionalism supported by lesson study. This case showed that there are crucial advantages of the lesson study obtained by the lesson study team related to continuous material development, classroom management, and teaching professionalism increase.

The implementation of e-portfolio which was carried out through several steps, namely plan, do, and evaluation through lesson study becomes an effective way in Cell Biology class. The number of feedback obtained during the implementation of lesson study related to the eportfolio makes it more effective in organizing the students' assignment and developing the student thinking concept, the metacognitive skill, and the learning activity. This result is in line with (e.g. [34,35,36]) that the implementation of lesson study of a certain topic and begun with the planning action, optimize the 'do' process and impact the result. Basically, as one of teaching media, e-portfolio can effectively and efficiently monitor the students' progress personally through the uploaded learning result, as in [5].

The implementation of e-portfolio monitored systematically through the implementation of lesson study will be the effective feedback to improve the lecturing quality. Reference [37,38] shows revealed the same condition that the integration of IT in learning activity, such as e-learning and e-portfolio done consistently, stimulated the students to be more focus enhancing their comprehending compared to that without IT. On the other hand, the development of e-portfolio through lesson study also provides more time for the students to think of and revise their assignments before bringing the topic to the discussion forum. Hence, the students can activate the metacognitive skill that can affect their concept comprehension.

Both the lesson study team and the students aware the impact of the integration of lesson study and e-portfolio. As a process, lesson study can build a conducive situation to improve the learning quality through sharing knowledge, material, and the students' characters in learning. Reference [39] shows that lesson study provides many experiences in terms of preparing the learning activity compared to individual preparation. Therefore, the implementation of lesson study is not only affecting the professionalism improvements in teaching but also the students' comprehension development (e.g. [40,41]). This result is in line with the statement of an observer saying that see delivering the student need is not restricted only in the context of cognitive but also related to other skills to control and communicate the learning result individually in order to build the comprehending and learning attitude.

\section{Conclusion}

The result of the study showed that the implementation and the development of e-portfolio supported by lesson study are able to improve the lecturing process, the metacognitive skill and the concept comprehension of Cell Biology of the students. The average score of e-portfolio students related to metacognitive skill and concept comprehention of Cell Biology is higher than that of portfolio students. Therefore, the implementation of lesson study can succesfully optimize the Internet application in terms of e-portfolio, so the students are capable to raise their learning process as well as their learning outcomes.

\section{Acknowledgement}

I would like to give my great appreciation to the head of IKIP PGRI Madiun, Indonesia Dr Parji, M.Pd., who had permitted me to carry out my research at the university. My great appreciation is given too to my dissertation Promotor Dra. Herawati Susilo, M.Sc, PhD., who had guided me in conducting the research.

\section{References}


[1] Kicken,W., Gruwel,S.,B., Merrienboer,J.G., dan Slot.,W. The Effects of Portfolio-based Advice on the Development of Selfdirected Learning Skills in Secondary Vocational Education. Educational Technology Research and Development. 57 (4). 439460. 2009

[2] Kwok, L. College Students' Participation in E-Portofolio Learning in Relation to Academic Ability and Motivation. Electronic Journal of Foreign Language Teaching. 8 (2). 246-267. 2011.

[3] Barrett, H.C. Create Your Own Electronic Portfolio:Using Offthe-Shelf Software to Showcase Your Own or Student Work. Learning \& Leading with Technology, 27 (7). 15-21. 2000.

[4] Klenowski,V., Askew,S., dan Carnell, E. Portfolios for Learning, Asessment and Professional Development in Higher Education. Asessment \& Evaluation in Higher Education. 31 (3). 267-286. 2006.

[5] Ahn, J. Electronic Portfolios: Blending Technology, Accountability \& Asessment. T.H.E. Journal, 31 (9). 12-18. 2004.

[6] Flavel,J.H. Metacognition and Cognitive Monitoring: A New Area of Cognitive-Development Inquiry. American Psychologist. 34. 906-911. 1979.

[7] Marcel,V.J., Veenman, Kok R., and Blote,A.W. The Relation Between Intelectual and Metacognitive Skills in Early Adolescence. Instructional Science. 33. 193-211. 2005.

[8] Ohayon,I.H., Kravetz,S., Levy,I., and Roe,D. Metacognitive and Interpersonal Intervention for Persons with Severe Mental Illness: Theory and Practice. Isr Journal Psychiatry Relat Sci. 46 (2): 141148. 2009.

[9] Maqsud,M. Effects of Metacognitve Skills and Nonverbal Ability on Academic Achievement of High Scholl Pupils. Educational Psychology. 17 (4). 387-398. 1997.

[10] Juznic,P., and Pymm,B. Student on Placement: Building Their Eportfolio From Practical Experience. World Library and Information Congress: 76 Th IFLA General Conference and Asembly. 2010.

[11] Amaya, P., Agudo,J.E., Sanchez.H., Rico,M., Linares,H.L. Educational E-portfolios: uses and tools. Procedia-Social and Behavioral Science. (93). 1169-1173. 2013.

[12] Gorbunovs,A., Kapenieks,A., and Kudina,I. Competence Development in a Combined Asessment and Collaborative Eportfolio Information System. Procedia-Social and Behavioral Science. (26). 79-100. 2013.

[13] Chau,J. dan Cheng, G. Towards Understanding the Potential of ePortofolio for Independent Learning: A qualitative Study. Australian Journal of Educational Technology. 26 (7). 932-950. 2010.

[14] Cheng Chang, Chi. Self-Evaluated Effects of Web-Based Portfolio Asessment System For Various Student Motivation Levels. J.Educational Computing Research. 41 (4). 391-405. 2009.

[15] Park,S.Y. An Analisis of The Technology Acceptance Model in Understanding University Students' Behavioral Intention to Use eLearning. Educational Technology \& Society, 12 (3). 150-162. 2009.

[16] Ono,Y., and Ferreira J. A Case Study of Continuing Teacher Proffesional Develpment Through Lesson Study in South Africa. South African Journal of Education. (30). 59-74. 2010.

[17] Diah A. Implementing Lesson Study in Microteaching of Presevice Teachers. Makalah. Dipresentasikan dalam International Conference on Lesson Study di Universitas Indonesia. 2008.

[18] Taylor, A.R., Anderson, S., Meyer, K., Wagner, M. K., and West, C., Lesson Study: A Professional Development Model for Mathematics Reform. The Rural Educator, 17-21. 2005.

[19] Lukitasari, M. Penggunaan Jurnal Belajar Berbasis Lesson Study untuk Identifikasi Proses Berpikir dan Pemahaman Konsep Mahasiswa di Perkuliahan Biologi Sel. Prosiding SemNas $X$ Pendidikan Biologi FKIP UNS. 171-177. 2013.

[20] Marsigit. Mathematics Teachers' Professional Development through Lesson Study in Indonesia. Eurasia Journal of Mathematics, Science \& Technology Education. 3 (2). 141-144. 2007.

[21] Tim Lesson Study. Laporan Pelaksanaan Kegiatan LS FP MIPA IKIP PGRI MADIUN. Laporan Kemajuan Pelaksanaan LS. Tidak dipublikasikan. 2011.
[22] Susilo,H. FINAL REPORT: Improvement of Secondary School Education, IMSTEP-JICA Project. 2003.

[23] Veselinovska,S.S., Gudeva,L.K., and Djokic,M. Applying Appropriates Methods for Teaching Cell Biology. Procedia Social and Behavioral Sciences. (15). 2837-2842. 2011.

[24] Smith,E.J. A Guide for Implementing Lesson Study for District and School Leadership Teams in Differentiated Accountability Schools. Florida Department of Education. 2010.

[25] Tuckman,B.W. Conducting Educational Research. 5 th Edition. New York: Hartcourt Brace College Publishers. 1999.

[26] Corebima,A.D. Metakognitive Skill Measurement Integrated In Achievement Test. SM310509ADC. 2006.

[27] Rock,T.C., and Wilson,C. Improving Teaching Through Lesson Study. Teacher Education Quarterly. 77-92. 2005.

[28] Ellerani., P., and Mendoza, M.J.G., A Participatory Process to Build and Improve the Competence Profile of Teacher UsingePortfolio. A case Study in a Higher Education Network. ProcediaSocial and Behavioral Science. 83. 659-666. 2013.

[29] Matanluk,K., Johari,K., and Matanluk,O. The Perception of Teachers and Students Toward Lesson Study Implementation at Rural School of Sabah: A Pilot Study. Procedia-Social and Behavioral Science. 90. 245-250. 2013.

[30] Alexiou,A., and Paraskeva.,F. Enhancing Self-Regulated Skills Through The Implementation of an E-portfolio Tool. Procedia Social and Behavioral Sciences. 2. 3048-3054. 2010.

[31] Nostratinia, M., and Adibifar, S. The Effect of Teaching Metakognitive Strategies on Field-dependent and Independent Learners' Ability. Procedia Social and Behavioral Sciences. 98; 1390-1399. 2014.

[32] Nesusin,N., Intrarakhamhaeng,P., Supadol,P., Piengkes,N., and Poonpipathana,S.. Development of Lesson Plant by The Lesson Study Approach for the $6^{\text {th }}$ Grade Students in Social Study Subject Based on Open Approach Innovation. Procedia-Social and Behavioral Science. 116; 1411-1415. 2014.

[33] Inprasitha,N. Perceptions on Proffessional Development of Supervisors in the Non-Project and Project Schools Using Lesson Study. Procedia-Social and Behavioral Science. 116; 2069-2073. 2014.

[34] Abidin,A.,Z. And Saleh,F. Soft Skills in the Development on Team-Based Electronic Learning Portfolio. Procedia Social and Behavioral Sciences. 8. 626-633. 2010.

[35] Yuk,K.,P., Critical Conditions for Pre-Service Teachers’ Learning Through Inquiri. The Learning Study Approach in Hongkong. International Journal for Lesson and Learning Studies. 1 (1). 4963. 2012.

[36] Isoda,M. Lesson Study: Problem Solving Approaches in Mathematics Education as a Japanese Experience. Procedia-Social and Behavioral Science. 8. 17-27. 2010.

[37] Al-Adwan,A., Al-Adwan,A., and Smedley,J. Exploring Students Acceptance of E-learning Using Technology Acceptance Model in Jordanian Universities. International Journal of Education and Development Using Information and Communication Technology (IJEDICT). 9 (2). 4-18. 2013.

[38] Umar, I.,N., and Yusoff, M.,T. A Study on Malaysian Teachers' Level of ICT skills and Practices, and its Impact on Teaching and Learning. Procedia Social and Behavioral Sciences. 116; 979-984. 2014.

[39] Yoshida,M. Exploring Ideas for a Mathematics Teacher Educator's Constribution to Lesson Study. The International Handbook of Mathematics Teachers Education. Vol. 2. Tools and Processes in Mathematics Teacher Education. Sense Publisher, 815. 2008.

[40] Kanauan,W., and Inprasitha, N. Collaboration Between Inservice Teachers and Student Intern in Thai Lesson Study. ProcediaSocial and Behavioral Science. 116. 28-32. 2014.

[41] Dudley, P. Lesson Study Development in England: From School Networks to National Policy. International Journal for Lesson and Learning Studies. 1 (1). 85-100. 2012. 